
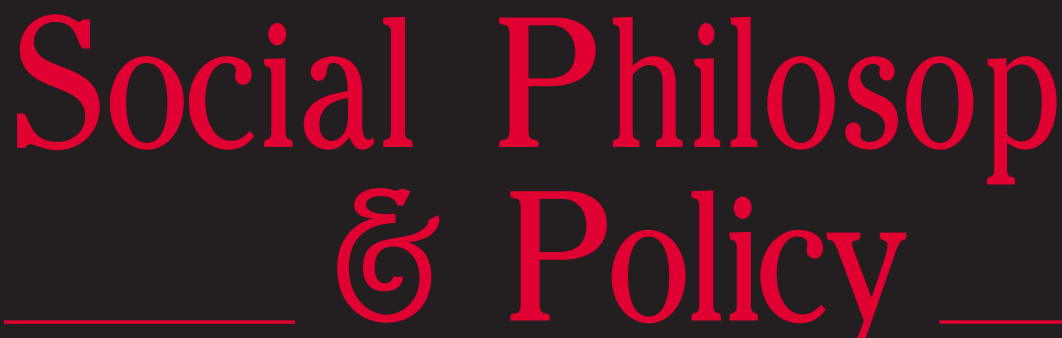

\title{
The Origins of Political Economy
}

DAVID SCHMIDTZ

CHRISTOPHER J. BERRY

RICHARD BOYD

MICHAEL B. GILL

NATALIE GOLD

SHAUN P. HARGREAVES HEAP

LEONIDAS MONTES

JAMES A. HARRIS

MARIA PIA PAGANELLI

JAMES R. OTTESON

MARGARET SCHABAS

TIMOTHY M. COSTELLOE

LOREN LOMASKY

\section{CONTENTS}

Origins of Political Economy

Out of the Coffee House or How Political

Economy Pretended To Be A Science from

Montchrétien to Steuart

The Early Modern Origins of Behavioral

Economics

Shaftesbury on Selfishness and Partisanship

55

How Should We Reconcile Self-Regarding and Pro-Social Motivations? A Renaissance of

"Das Adam Smith Problem"

Two Accounts of the Relation between Political Economy and Economics (And Why It Matters Which Account Is Better)

The Relevance of Propriety and Self-Command in Adam Smith's Theory of Moral Sentiments

The Protection of the Rich against the Poor:

The Politics of Adam Smith's Political Economy

Adam Smith and the Origins of Political Economy

The Levellers and the Birth of Liberal Political

Economy

David Hume as a Proto-Weberian: Commerce,

Protestantism, and Secular Culture

"Shining Bits of Metal": Money, Property, and the Imagination in Hume's Political Economy

Polity and Economy in Plato's Republic 


\section{Social Philosophy ๘ Policy}

ISSN 0265-0525

Editor: David Schmidtz

Founder and Editor Emeritus: Ellen Frankel Paul

Executive Editors: Fred D. Miller, Jr., and Jeffrey Paul

Associate Editors: Carmen Pavel and Bas van der Vossen

Administrative Editor: Tamara Sharp

Managing Editor: Sarah Raskoff

Assistant Editor: Pamela Phillips

Baruch Brody

Rice University

Jules L. Coleman

New York University

Tyler Cowen

George Mason University

Richard A. Epstein

New York University School of Law

James S. Fishkin

Stanford University

Gilbert Harman

Princeton University

\section{Editorial Board}

Daniel Jacobson

University of Colorado, Boulder

Chandran Kukathas

London School of Economics and

Political Science

Loren Lomasky

University of Virginia

Eric Mack

Tulane University

Harvey C. Mansfield

Harvard University

Michael C. Munger

Duke University
Jan Narveson

University of Waterloo

Nicholas Rescher

University of Pittsburgh

Geoffrey Sayre-McCord

University of North Carolina-Chapel Hill

Hillel Steiner

University of Manchester

University of Arizona

Michael Zuckert

University of Notre Dame

$\begin{array}{ll}\text { Michael Douma } & \text { Patrick Müller } \\ \text { Georgetown University } & \text { Friedrich-Alexander Universität } \\ \text { Keith Hankins } & \text { Eric Schliesser } \\ \text { Chapman University } & \text { University of Amsterdam } \\ \text { Brian Kogelmann } & \text { Virgil Storr } \\ \text { University of Maryland } & \text { George Mason University } \\ \text { Jayme Lemke } & \text { John Thrasher } \\ \text { Mercatus Center } & \text { Chapman University } \\ \text { Jacob Levy } & \text { Fabian Wendt } \\ \text { McGill University } & \text { Chapman University } \\ \text { Fred D. Miller, Jr. } & \text { Bart Wilson } \\ \text { Social Philosophy \& Policy Foundation } & \text { Chapman University }\end{array}$

Copyright (C) 2020 Social Philosophy and Policy Foundation

All rights reserved. No part of this publication may be reproduced, in any form or by any means, electronic, photocopying or otherwise, without permission in writing from Social Philosophy \& Policy. Photocopying information for users in the USA: The Item-Free Code for this publication (0265-0525/12 \$15.00) indicates that copying for internal or personal use beyond that permitted by Sec. 107 or 108 of the U.S. Copyright Law is authorized for users duly registered with the Copyright Clearance Center (CCC) Transaction Reporting Service, provided that the appropriate remittance is paid directly to: CCC, 222 Rosewood Drive, Danvers, MA 01923. Specific written permission must be obtained from Social Philosophy $\mathcal{E}$ Policy for all other copying.

Social Philosophy E Policy is a registered trademark owned by the Social Philosophy and Policy Foundation. 